\title{
TINJAUAN YURIDIS PERTANGGUNGJAWABAN PIDANA PENCEMAR LINGKUNGAN HIDUP
}

Oleh:

\section{Bangun Patrianto}

\begin{abstract}
conventional Law teaching express that each;every deed impinge the law harming other party, hence side the maker is obliged to change with a number of money utilize to cure if proven in the face of mistake conference of maker, but the rule have been infiltrated by principle of justice absolute responsibility strict liability what cirrithe core important for example incidence direct responsibility and at once at the time of the happening of deed, so that needn't be related to bya mistake element fault, schuld.
\end{abstract}

Keyword : Environmental Responsibility, Mistake, Strict Liability.

\section{LATAR BELAKANG}

Pada awalnya masalah lingkungan hidup bukanlah masalah yang serius, karena sifat dari masalah yang timbul merupakan masalah yang bersifat alami berupa peristiwa-peristiwa yang terjadi sebagai bagian dari proses natural tanpa menimbulkan akibat yang berarti bagi tata lingkungan itu sendiri dan dapat pulih seperti sedia kala di kemudian hari secara alami pula, sehingga dapat dikatakan tidak menimbulkan masalah yang berarti sama sekali bagi alam itu sendiri.

Selanjutnya masalah lingkungan berkembang dan tidak lagi semata-mata bersifat alami, karena manusia merupakan faktor penyebab yang sangat besar dalam peristiwa-peristiwa lingkungan, seperti pencemaran, kerusakan sumber daya alam, musnahnya berbagai spesies hayati, banjir, tanah longsor, bahkan berbagai jenis penyakit yang ada diyakini merupakan gejala negatif yang dominan bersumber dari perbuatan manusia.

Dengan demikian masalah lingkungan semakin hari semakin membesar, meluas dan serius. Persoalannya tidak hanya bersifat lokal atau translokal, tetapi regional, nasional, transnasional, bahkan mendunia. Dampak yang terjadipun terhadap lingkungan tidak hanya bersifat dan terkait pada satu atau dua segi saja, akan tetapi saling mengkait sesuai dengan sifat lingkungan yang 
memiliki multi hubungan yang saling mempengaruhi secara sistem.

IImu hukum perdata telah mengajarkan bahwa setiap perbuatan manusia atau badan hukum yang melanggar hukum atau yang bertentangan dengan hukum, kemudian perbuatan tersebut menimbulkan sejumlah kerugian kepada pihak lain, maka kepada pembuat kesalahan harus bertanggung jawab untuk membayar atau mengganti sejumlah kerugian atas akibat yang telah ditimbulkannya tersebut. Hal ini sesuai dengan ketentuan yang diatur dalam pasal 1365 Kitab Undang-Undang Hukum Perdata (selanjutnya disebut KUHPerdata) yang berbunyi : Tiap perbuatan melanggar hukum, yang membawa kerugian kepada seorang lain, mewajibkan orang yang karena salahnya menerbitkan kerugian itu, mengganti kerugian tersebut.

Jenis-jenis tanggung gugat pencemaran lingkungan hidup menurut Undang-Undang Republik Indonesia Nomor 23 Tahun 1997 tentang Pengelolaan Lingkungan Hidup (selanjutnya disebut UUPLH) yang salah satu bentuknya adalah perbuatan yang merugikan pihak lain yang berupa pencemaran lingkungan hidup dan/atau kerusakan lingkungan hidup.

Pencemaran lingkungan atau perusakan lingkungan, maupun apa saja yang dikategorikan merugikan orang atau pihak lain dalam kepentingan lingkungan hidupnya, termasuk sebagai perbuatan melawan hukum (onrechtsmatigedaad). (N.H.T. Siahaan, 2005: 307)

Dalam UUPLH, ketentuan yang mengatur tentang pertanggungjawaban atas pencemaran lingkungan hidup diatur dalam ketentuan pasal 34 ayat (1) dan pasal 35 ayat (1). Masing-masing pasal tersebut mengatur dan menganut sifat pertanggungjawaban yang berbeda yakni:

a. Pasal 34 ayat (1) UUPLH mengatur dasar dan sifat pertanggungjawaban yang biasa seperti diatur dalam ketentuan pasal 1365 KUHPerdata yang mensyaratkan adanya pembuktian kesalahan pelaku ;

b. Pasal 35 ayat (1) UUPLH mengatur dasar dan sifat pertanggungjawaban yang khusus yang merupakan pengecualian ketentuan pasal 1365 KUHPerdata dan diatur 
PERSPEKTIF Volume X No.3 Tahun 2005 Edisi Juli

tersendiri dalam UUPLH ini.

Berdasarkan uraian tersebut maka yang menjadi persoalan dalam penelitian ini adalah Bagaimana pembuat pencemaran lingkungan hidup bertanggungjawab atas kerusakan lingkungan hidup baik menurut ketentuan pasal 34 ayat (1) maupun pasal 35 ayat (1) UUPLH?

\section{TANGGUNG JAWAB PENCEMAR MENURUT KETENTUAN PASAL 1365 KUHPerdata}

Maksud dari ketentuan pasal 1365 KUHPerdata adalah setiap perbuatan yang bertentangan dengan hukum harus dipertanggungjawabkan atas kerugian-kerugian yang diderita oleh pihak lain. Perbuatan melanggar hukum (onrechtmatige daad) menurut perkembangan dan sejarahnya berawal dari yurisprudensi yang tidak saja mencakup perbuatan yang bertentangan dengan hukum dan hak dari pihak lain, tetapi juga setiap perbuatan yang bertentangan dengan kepatutan dalam pergaulan masyarakat, baik dalam hubungannya dengan pribadi maupun harta benda orang lain.
Putusan Hoge Raad 1919 tertanggal 31 Januari 1919 tentang penafsiran perbuatan melawan hukum yang diatur dalam pasal 1365 KUHPerdata. Di dalam putusan Hoge Raad 1919 definisi perbuatan melawan hukum, tidak hanya melawan undangundang, tetapi juga melanggar hak-hak subjektif orang lain, kesusilaan, dan ketertiban umum.

Menurut Salim H.S dalam bukunya Hukum Kontrak mengatakan menurut HR 1919 yang diartikan dengan perbuatan melawan hukum adalah berbuat atau tidak berbuat yang :

1. melanggar hak orang lain;

Yang dimaksud dengan hak orang lain, bukan semua hak, tetapi hanya hak-hak pribadi, seperti integritas tubuh, kebebasan, kehormatan, dan lain-lain termasuk dalam hal ini hak-hak absolute, seperti hak kebendaan, hak atas kekayaan intelektual (HAKI), dan sebagainya.

2. bertentangan dengan kewajiban hukum pelaku ;

Kewajiban hukum hanya kewajiban yang dirumuskan dalam aturan undang-undang ; 
3. bertentangan dengan kesusilaan, artinya perbuata yang dilakukan oleh seseorang itu bertentangan dengan sopan santun yang tidak tertulis yang tumbuh dan berkembang dalam masyarakat;

4. bertentangan dengan kecermatan yang harus diindahkan dalam masyarakat;

Atura tentang kecermata terdiri dari dua kelompok yaitu :

(1) aturan-aturan yang mencegah orang lain terjerumus dalam bahaya, dan

(2) aturan-aturan yang melarang merugikan orang lain ketika hendak menyelenggarakan kepentingannya sendiri (Salim, 2003:8).

Menurut Djasadin Saragih dalam bukunya Pokok-Pokok Hukum Perikatan mengatakan sejak 1919 (HR 31-1-1919, RJ 1919, 161; Lindenbaum/ Cohen) yang diartikan dengan perbuatan melanggar hukum adalah berbuat atau tidak berbuat yang (1) melanggar hak orang lain; atau
(2) bertentangan dengan kewajiban hukum pelaku ; atau (3) bertentangan dengan kesusilaan; atau (4) bertentangan dengan kecermatan yang harus diindahkan dalam lalu lintas masyarakat terhadap diri dan barang orang lain (Djasadin Saragih, 1985: 118)

Ketentuan yang diatur oleh pasal 1365 KUHPerdata berbeda dengan yang diatur dalam pasal 1366 KUHPerdata. Pasal 1365 KUHPerdata mengatur asas hukum tanggung jawab secara kesalahan (fault) artinya pembuat perbuatan dalam melakukan perbuatan yang merugikan pihak lain tersebut dilakukan dengan sengaja, sedang pasal 1366 KUHPerdata mengatur asas hukum tanggung jawab secara kelalaian artinya pembuat perbuatan dalam melakukan perbuatan yang merugikan pihak lain tersebut dilakukan dengan kelalaian atau ketidaksengajaan.

Menurut N.H.T. Siahaan dalam bukunya Hukum Lingkungan dan Ekologi Pembangunan mengatakan : asas pertanggungjawaban secara kesalahan (fault) didasarkan pada adagium bahwa tidak ada pertanggungjawaban apabila tidak terdapat unsur kesalahan (No 
Liability Without Fault).

Pertanggungjawaban demikian, menurut ilmu hukum disebut dengan "Tortious Liability" atau "Liability Based On Fault" (N.H.T. Siahaan : 2004 : 307).

Adapun unsur-unsur pasal 1365 KUHPerdata tentang perbuatan melanggar hukum (Onrechtsmatige daad) adalah :

a. adanya perbuatan yang harus bersifat melawan hukum ;

b. adanya kesalahan pada diri pembuat atau pelaku ;

c. adanya kerugian bagi korban ; dan

d. adanya hubungan kausalitas antara perbuatan yang bersifat melawan hukum dengan kerugian yang diderita oleh pihak lain.

Adanya perbuatan melanggar hukum diawali oleh perbuatan oleh pelakunya.

Perbuatan yang dimaksudkan adalah, baik berbuat sesuatu maupun tidak berbuat sesuatu. Contoh A tidak berbuat sesuatu pada hal A mempunyai kewajiban hukum untuk berbuat, kewajiban mana timbul dari hukum yang berlaku, sebab ada pula kewajiban yang timbul dari suatu kontrak. Terhadap perbuatan melanggar hukum tidak ada unsur persetujuan atau kata sepakat dan tidak ada causa yang diperbolehkan sebagaimana yang terdapat alam kontrak.

Perbuatan melawan hukum sejak tahun 1919 telah ditafsirkan dengan seluas-luasnya yang dikenal dengan perbuatan melanggar hukum materiil, yang meliputi hal-hal sebagai berikut :

a. Perbuatan yang melanggar undang-undang yang berlaku ;

b. Yang melanggar hak orang lain yang dijamin oleh hukum ;

c. Perbuatan yang bertentangan dengan kewajiban hukum si pelaku ;

d. Perbuatan yang bertentangan dengan kesusilaan (geode zeden)

e. Perbuatan yang bertentangan dengan sikap yang baik dalam bermasyarakat untuk memperhatikan kepentingan orang lain ;

Suatu perbuatan melawan hukum agar dapat memenuhi ketentuan pasal 1365 KUHPerdata, maka undang-undang dan yurisprudensi sebagai sumber bahan hukum primer dalam Negara yang menganut sistem hukum Eropa

Continental telah mensyaratkan agar pada diri pelaku haruslah terbukti di muka sidang pengadilan elemen 
PERSPEKTIF Volume X No.3 Tahun 2005 Edisi Juli

kesalahan (schuldelement) dalam melakukan perbuatannya. Kecuali undang-undang menentukan lain misalnya tanggung jawab tanpa kesalahan (Strict liability) adalah tidak termasuk dalam pengertian tanggung jawab berdasar pada ketentuan pasal 1365 KUHPerdata, sebab ketentuan pasal 1365 KUHPerdata menyaratkan suatu keharusan yang terbukti di muka sidang pengadilan elemen kesalahan (Schuld) dalam perbuatan melanggar hukum yang terdapat dalam subyektif diri si pelaku.

Suatu perbuatan dianggap oleh hukum terdapat elemen kesalahan sehingga dapat dituntutkan kepada pembuat akan tanggung jawabnya secara hukum apabila di dalam diri pelaku sebagai unsur subyektif dalam perbuatannya sebagai unsur obyektif memenuhi unsur kesengajaan (dolus atau opzet) atau kelalaian (culpa) dan tidak ada alasan pembenar (justification) atau alasan pemaaf (rechtvaar digingsgrond). Sebagai contoh alasan peniadaan pidana menurut undangundang yang bersifat umum yakni keadaan terpaksa membela diri (noodware) yang diatur dalam pasal 49
Kitab Undang-Undang Hukum Pidana (selanjutnya disebut KUHP), keadaan memaksa darurat diluar kekuasaannya (overmacht) yang diatur dalam pasal 48 KUHP, kemudian juga yang diatur dalam pasal 44 (terganggu jiwanya), pasal 50 (melaksanakan ketentuan undangundang, pasal 51 ayat (2) (melaksanakan perintah jabatan yang tidak berwenang dengan iktikad baik, yang masih dalam lingkup tugas pekerjaannya. Sedangkan alasan peniadaan pidana menurut undang-undang yang bersifat khusus adalah tersebar dalam rumusan beberapa tindak pidana, misalnya adanya alasan demi untuk kepentingan umum atau untuk kepentingan membela diri sebagai dasar peniadaan pidana dari pencemaran (pasal 310 ayat 3)

Selain itu ada alasan peniadaan pidana diluar undang-undang yang dianut dalam praktek yakni hapusnya sifat melawan hukum (materiil) perbuatan dan tidak adanya kesalahan(SCHULD) pada diri pelaku atau pembuat.

Diperlukannya baik unsur perbuatan melanggar hukum dan unsur kesakahan sekaligus dalam ketentuan pasal 1365 KUHPerdata, karena dalam unsur melawan hukum saja belum tentu 
mencakup unsur kesalahan, di negeri Belanda aliran ini dianut misalnya oleh Meyers (Munir Fuady, 2005 : 13).

Selanjutnya Munir Fuady berpendapat kesalahan yang disyaratkan oleh hukum dalam perbuatan melawan hukum, baik kesalahan dalam arti "kesalahan hukum" maupun "kesalahan social". Dalam hal ini hukum menafsirkan kesalahan sebagai suatu kegagalan seseorang untuk hidup dengan sikap yang ideal, yakni sikap yang biasa dan normal dalam suatu pergaulan masyarakat.

Sikap yang demikian kemudian mengkristal dalam istilah hukum yang disebut dengan standar "manusia yang normal dan wajar" (reasonable man) (Munir Fuady, 2005: 13).

Namun teori atau pendapat Munir Fuady yang mengatakan bahwa sikap yang demikian kemudian mengkristal dalam istilah hukum yang disebut dengan standar "manusia yang normal dan wajar" masih sepenuhnya diragukan kebenarannya, karena Pertama : tujuan hukum sendiri adalah untuk mencari dan menegakkan kebenaran, sedangkan persoalan apa yang terjadi di masyarakat belum diuji kebenarannya dalam bentuk pembuktian oleh para pihak. Kedua : kesalahan adalah unsur subyektif yang terletak dalam diri si pelaku kejahatan dari suatu perbuatan yang telah ia lakukan, sehingga kebenarannya menjadi semakin sulit untuk disimpulkan dalam kerangka yang obyektif. Ketiga : Keadaan masyarakat juga perlu dikaji, apakah seseorang itu berada di suatu lingkungan yang baik dan benar? artinya apabila seseorang yang baik dan benar ada dalam lingkungan yang rusak dan tidak baik apakah ia harus ikut rusak demi mengejar standar "manusia yang normal dan wajar" (reasonable man)? Menurut penulis justru seseorang harus dapat mempengaruhi dan mengajak kepada masyarakat yang tidak baik menuju kepada masyarakat yang baik, minimal dengan memberikan contoh dan suri tauladan kepada masyarakat dan bukan justru sebaliknya ia terpengaruh dalam ketidakbenaran di masyarakat.

Bagi pihak korban, kerugian yang diderita akibat perbuatan melanggar hukum yang dilakukan oleh pihak lain, maka pihak korban harus mendapatkan pemulihan dalam bentuk penggantian 
PERSPEKTIF Volume X No.3 Tahun 2005 Edisi Juli

kerugian sejumlah uang.

Berbeda dengan kerugian karena wanprestasi yang hanya mengenal kerugian materiil, maka untuk kerugian karena perbuatan melanggar hukum (onrechtsmatige daad) disamping kerugian materiil, juris prudensi mengakui pula konsep kerugian immateriil yang akan dinilai dengan sejumlah uang.

\section{TANGGUNG JAWAB MUTLAK}

Di dalam hukum lingkungan, khususnya dalam UUPLH, selain jenis pertanggungjawaban perdata yakni sebagai bentuk pertanggungjawaban atas perbuatan melanggar hukum (onrechtsmatige daad) yang mengkaitkan dengan terbuktinya suatu kesalahan pelaku terlebih dahulu seperti yang diatur dalam ketentuan pasal 1365 KUHPerdata dan kemudian substansi ketentuan tersebut dipedomani dan dicantumkan dalam pasal 34 ayat 1 UUPLH.

Unsur-unsur pokok perbuatan melawan hukum adalah adanya perbuatan yang memiliki sifat melawan hukum, adanya kesalahan (fault, schuld), adanya kerugian dan adanya hubungan sebab akibat antara perbuatan dengan kerugian. Perbuatan melanggar hukum pada teori yang konvensional didasarkan pada adanya kesalahan (liability based on fault), karena tanpa adanya kesalahan, tidak akan timbul dasar untuk menuntut kerugian.

Bagaimana membuktikan kesalahan pelaku atas perbuatan yang melanggar hukum di depan pengadilan? Memang tidaklah mudah untuk membuktikan adanya kesalahan, karena pihak penggugat harus terlebih dahulu membuktikan adanya hubungan kausal atau hubungan sebab akibat antara perbuatan pencemaran dengan kerugian yang diderita oleh korban. Jika untuk masalah lingkungan, maka tentang hal membuktikan adalah dengan menjelaskan hubungan sebab akibat dari perbuatan pelaku pencemaran dengan kerugian pihak korban. Mengaudit, menganalisis suatu perbuatan mencemarkan lingkungan hidup membutuhkan penjelasan yang bersifat ilmiah, rasional, logis, dan sangat teknis, sehingga apabila skalanya bersifat meluas serta serius, maka untuk membuktikan adanya hubungan sebab akibat dalam masalah pencemaran lingkungan hidup akan lebih sulit. Oleh karena itu, penerapan sistem pertanggung jawaban yang bersifat konvensional dalam 
PERSPEKTIF Volume X No.3 Tahun 2005 Edisi Juli

penyelesaian sengketa lingkungan hidup tidaklah mencerminkan rasa keadilan, lebih-lebih rasa keadilan sosial.

Walaupun pembentuk undangundang tidak menyatakan dengan tegas bahwa dalam pencemaran dan/atau perusakan lingkungan hidup seperti yang dimaksud dalam ketentuan pasal 34 ayat (1) UUPLH itu oleh pembuat pencemaran harus dilakukan "dengan sengaja", apalagi tidak dapat disangkal lagi kebenarannya bahwa perbuatan melanggar hukum yang berupa pencemaran dan/atau perusakan lingkungan hidup "harus" dilakukan oleh pembuat "dengan sengaja" yakni karena dalam peraturan perundang-undangan yang berlaku, khususnya UUPLH ini tidak mengenal lembaga perbuatan melanggar hukum dalam pencemaran dan/atau perusakan lingkungan hidup yang dilakuan dengan tidak sengaja atau culpoos diefstal.

Pembuktian kesalahan in casu kesengajaan atau opzet pembuat di muka persidangan harus meliputi semua unsurunsur yang meliputi seluruh norma dalam ketentuan pasal yang mengaturnya, pasal 34 ayat (1) UUPLH.

Hal penting dari pengertian dengan sengaja atau opzet itu adalah willens en wetens atau menghendaki dan mengetahui. Karena yang dapat dikehendaki atau yang dapat dimaksud itu hanyalah perbuatanperbuatan, sedangkan keadaankeadaan itu hanya dapat diketahui, sehingga untuk dapat menyatakan seseorang pembuat pencemaran dan/atau perusakan lingkungan hidup telah memenuhi unsur kesengajaan atau opzet sebagaimana yang dimaksudan oleh ketentuan pasal 34 ayat (1) UUPLH, maka di muka sidang pengadilan yang memeriksa dan mengadili sengketa, pembuat pen-cemaran harus terbukti oleh pihak penggugat bahwa tergugat:

a. telah menghendaki atau bermaksud untuk melakukan perbuatan pencemaran dan/atau perusakan ;

b. mengetahui bahwa yang dicemarinya dan/atau dirusaknya adalah lingkungan hidup ;

c. mengetahui bahwa usaha dan kegiatannya menimbulkan kerugian ;

d. mengetahui bahwa yang dirugikan adalah orang lain atau lingkungan hidup ;

Apabila kehendak, maksud atau pengetahuan-pengetahuan ataupun 
PERSPEKTIF Volume X No.3 Tahun 2005 Edisi Juli

salah satu dari kehendak, maksud atau pengetahuan-pengetahuan pembuat pencemaran dan/atau perusakan lingkungan hidup sebagaimana yang dimaksudkan di atas itu ternyata tidak dapat dibuktikan maka tidak dapat dikatakan bahwa pembuat telah terbukti memenuhi unsur kesengajaan atau opzet untuk melakukan pencemaran dan/atau perusakan lingkungan hidup seperti yang dimaksud dalam pasal 34 ayat (1) UUPLH, sehingga hakim harus menjatuhkan putusan menolak gugatan pihak penggugat.

Istilah lain dari asas tanggung jawab mutlak yakni tanggung jawab langsung dan seketika (Strict Liability), yang telah dianut oleh UUPLH dalam ketentuan pasal 35 ayat (1). Unsur-unsur asas strict liability dalam UUPLH bersifat khusus, karena di dalam sistem pertanggung jawabannya, unsur-unsurnya telah diatur secara khusus dengan menunjuk kepada hal atau syarat tertentu sehingga dapat digolongkan ke dalam bentuk pertanggungjawaban tertentu pula.

Ciri utama dari asas strict liability antara lain adalah timbulnya tanggung jawab langsung dan seketika pada saat terjadinya perbuatan, sehingga tidak perlu lagi dikaitkan dengan unsur kesalahan (schuld, fault.).

Untuk mengetahui asas strict liability dimuat dalam ketentuan pasal 35 ayat (1) UUPLH, maka bunyi pasal tersebut sebagai berikut:

"Penanggung jawab usaha dan/atau kegiatan yang usaha dan kegiatannya menimbulkan dampak besar dan penting terhadap lingkungan hidup, yang menggunakan baha berbahaya dan beracun, dan/atau menghasilkan limbah bahan berbahaya dan beracun, bertanggung jawab secara mutlak atas kerugian yang ditimbulkan, dengan kewajiban membayar ganti rugi secara langsung dan seketika pada saat terjadinya pencemaran dan/atau kerusakan lingkungan hidup"

Sedangkan asas strict liability dengan gamblang telah disebut di dalam penjelasan pasal demi pasal dari ketentuan pasal 35 ayat(1) yang menyebutkan sebagai berikut :

"Pengertian bertanggung jawab secara mutlak atau strict liability, yakni unsur kesalahan tidak perlu dibuktikan oleh pihak penggugat sebagai dasar 
pembayaran ganti kerugian. Ketentuan ayat ini merupakan lex specialis dalam gugatan tentang perbuatan melanggar hukum pada umumnya. Besarnya nilai ganti rugi yang dapat dibebankan terhadap pencemar atau perusak lingkungan hidup menurut pasal ini dapat ditetapkan sampai batas tertentu yang dimaksudkan sampai batas tertentu, adalah jika menurut penetapan peraturan perundang-undangan yang berlaku, ditentukan keharusan asuransi bagi usaha dan/atau kegiatan yang bersangkutan atau telah tersedia dana lingkungan hidup".

Untuk lebih jelasnya dalam mengurai substansi ketentuan pasal yang mengandung asas tanggung jawab mutlak tersebut, maka harus mengetahui unsur-unsur dari ketentuan pasal 35 ayat (1) UUPLH yakni :

1. penanggung jawab:

2. suatu perbuatan atau usaha atau kegiatan ;

3. yang usaha dan kegiatannya menimbulkan dampak besar dan penting terhadap lingkungan hidup;

4. yang menggunakan bahan berbahaya dan beracun ; atau

5. yang menghasilkan limbah bahan berbahaya dan beracun ;

6. bertanggung jawab secara mutlak;

7. kerugian yang ditimbulkan;

8. wajib membayar ganti rugi ;

9. secara langsung dan seketika pada saat terjadinya pencemaran atau perusakan lingkungan ;

unsur-unsur tersebut harus terbukti di muka persidangan seluruhnya sehingga kepada tergugat akan dijatuhkan hukuman untuk membayar sejumlah kerugian yang diderita oleh pihak penggugat. Sebaliknya apabila salah satu unsur tersebut di atas tidak terbukti di depan persidangan maka gugatan penggugat ditolak seluruhnya.

Berdasarkan unsur-unsur tersebut, maka unsur tanggung jawab mutlak ada di unsur ke 6 dan unsur dan unsur tanggung jawab secara langsung dan seketika pada saat terjadinya pencemaran atau perusakan lingkungan ada di unsur ke 9.

Menurut Siti Sundari Rangkuti dalam bukunya "Hukum Lingkungan dan Kebijaksanaan Lingkungan Nasional" mengatakan bahwa tanggung gugat di sini timbul seketika pada saat terjadinya perbuatan, tanpa mempersoalkan kesalahan tergugat (Siti Sundari Rangkuti, 2005: 307) 
PERSPEKTIF Volume X No.3 Tahun 2005 Edisi Juli

Sebenarnya unsur strict liability sebenarnya sebagai suatu pengertian yang tampaknya asing dalam lembagalembaga hukum yang berlaku di Indonesia, baik dalam lapangan hukum privat maupun lapangan hukum publik, karena di dalam logika dan pengertian hukum yang telah lama dikenal dan pada umumnya, diterima suatu pengertian bahwa seseorang harus atau wajib bertanggung jawab atas setiap kerugian yang diderita oleh orang lain untuk menggantinya dengan sejumlah uang setelah ia dinyatakan terbukti bersalah oleh pengadilan. Artinya seseorang tidak dapat dibebankan kewajiban ber tanggungjawab, kecuali atas dasar kesalahan yang ada pada diri pembuat yang merupakan unsur subyektif dalam suatu norma hukum, sebagaimana prinsip ini dikenal dengan Tortius Liability.

Menurut Siti Sundari Rangkuti dalam bukunya "Hukum Lingkungan dan Kebijaksanaan Lingkungan Nasional" mengatakan tentang asas Tortius Liability yakni dengan demikian menurut Komar absolute liability menggunakan pola dasar perbuatan melawan hukum yang menimbulkan kerugian pada pihak lain (tort liability) dengan harus membuktikan adanya kesalahan (liability based on fault).

Selanjutnya pendapat Komar, dalam bukunya Siti Sundari Rangkuti tersebut menjelaskan tentang absolute liability adalah : pengertian pertanggungjawaban penuh/absolute mengandung 2 pngertian : pengertian procedural, yaitu kewajiban untuk melakukan pembuktian adanya unsur kesalahan untuk dapat di pertanggungjawabkannya kerugian (1), dan pengertian materiil, yaitu penuh dalam besarnya ganti rugi, yang mengandung pengertian bahwa pemberian ganti rugi harus sepenuhnya /tanpa batas tertinggi yang ditentukan terlebih dahulu (2). ( Siti Sundari Rangkuti, 2005 : 308)

$$
\text { Maksud pembentuk UUPLH }
$$
dengan menganut asas tanggung jawab mutlak dalam hukum materiil hendaknya diikuti oleh lembaga-lembaga peradilan di Indonesia dalam putusan-putusan pengadilan agar apa yang menjadi cita hukum dari pembentuk undang-undang untuk melaksanakan pembangunan berkelanjutan yang berwawasan lingkungan hidup dapat tercapai. Artinya pengadilan sebagai garda terdepan dalam penyelesaian sengketa lingkungan hidup dapat melakukan 
penyelamatan lingkungan hidup lebih awal dan lebih cepat.

Adapun cara yang dapat dilakukan oleh hakim dalam ikut berperan serta aktif dalam penyelamatan lingkungan hidup adalah hakim dengan independensinya dalam memutus sengketa lingkungan hidup dengan menghidupkan kembali lembaga hukum “ uitvoerbaar bij voorraad " atau biasanya dalam petitum surat gugatan dimohonkan oleh penggugat kepada Ketua Pengadilan Negeri setempat agar memutuskan dengan menyatakan putusan ini dapat dijalankan lebih dahulu ( uitvoerbaar bij voorraad), meskipun timbul verzet, banding maupun kasasi. Artinya putusan dapat dilaksanakan serta merta yang berarti pula putusan yang dijatuhkan dapat langsung dilaksanakan eksekusinya serta merta, meskipun putusan tersebut belum memperoleh kekuatan hukum tetap.

Menurut M. Yahya, baik berdasaran doktrin maupun pasal 195 dan 196 HIR, pemenuhan suatu putusan baru dapat dilaksanakan baik secara sukarela maupun paksa melalui eksekusi, apabila putusan pengadilan itu telah memperoleh kekuatan hukum tetap. Prinsip ini ditegaskan dalam putusan MA No. : 1043
K/1971. Dikatakan pelaksanaan putusan hakim, harus menunggu sampai seluruh putusan mempunyai ekuatan hokum tetap, meskipun salah satu pihak (tergugat) tidak banding atau kasasi, tetapi penggugat banding dan kasasi berarti putusan belum memperoleh kekuatan hukum tetap (res judicata), oleh karena itu belum dapat dieksekusi. (M.Yahya Harahap, 2004 : 897-898).

Dasar hukum yang mengatur tentang putusan yang dapat dilaksanakan terlebih dahulu adalah pasal 180 (1) H.I.R. dan pasal 191 (1) R.Bg., namun demikian Mahkamah Agung melalui Surat Edarannya yang lebih dikenal dengan SEMA MA. lebih sering mengeluarkan SEMA dan yang terakhir dikeluarkan adalah SEMA No. : 03 Tahun 1978 tanggal 1 April 1978, yang berisi agar para hakim di seluruh Indonesia tidak menjatuhkan putusan yang dapat dijalankan lebih dahulu (uitvoerbaar bij voorraad), meskipun syarat-syarat yang ditentukan dalam pasal 180 ayat (1) HIR, pasal 191 ayat (1) R.Bg terpenuhi. Berarti Mahkamah Agung tetap melarang untuk melaksanakan ketentuan pasal tersebut yang memerintahkan kepada pengadilan rendahan untuk tidak mengabulan per- 
PERSPEKTIF Volume X No.3 Tahun 2005 Edisi Juli

mohonan penggugat yang berkaitan dengan putusan yang dapat dijalankan lebih dahulu (uitvoerbaar bij voorraad), meskipun timbul verzet, banding maupun kasasi.

Dengan berkembangnya pengertian perbuatan melanggar hukum dan tanggung jawab mutlak yang dianut oleh UUPLH dengan tanpa pembuktian unsur kesalahan tergugat di muka hakim, yang merupakan pengecualian dari pasal 1365 KUHPerdata, maka SEMA a quo sudah tidak relevan lagi untuk dilaksanakan serta diharapkan oleh hukum dan para pencari keadilan agar pengadilan lebih obyektif dan mengikuti perkembangan ilmu hukum maupun perkembangan yurisprudensi, sehingga hakim di Indonesia tidak terkungkung pada pemahaman dan paradigma yang sempit dalam rangka pemahaman serta penyelamatan lingkungan hidup..

Kemudian pengecualian tanggung jawab diberikan kepada pembuat oleh pasal 35 ayat (2) UUPLH apabila pembuat dapat membuktikan bahwa pencemaran atau kerusakan berasal dari bencana alam, atau peperangan, atau keadaan terpaksa (force majeure) atau karena tindakan pihak ke-tiga. Apabila ternyata terbukti penyebabnya adalah pihak ke-tiga, maka pihak ke-tiga harus mengambil alih tanggung jawab atas kerugian korban (pasal 35 ayat (3) UUPLH).

\section{DAFTAR PUSTAKA}

Djasadin Saragih, S.H., LLM, 1985, Pokok-Pokok Hukum Perikatan, Penerbit Universitas Airlangga, Surabaya.

Munir Fuady, Dr. S.H.,M.H.,LLM, 2005, Perbuatan Melawan Hukum, Penerbit PT. Citra Aditya Bakti, Bandung.

M. Yahya Harahap, S.H., 2004, Hukum Acara Perdata, Penerbit Sinar Grafika, Jakarta

N.H.T. Siahaan, 2004, Hukum Lingkungan dan Ekologi Pembangunan, Penerbit Erlangga, Jakarta.

Siti Sundari Rangkuti, Prof.Dr., 2005, Hukum Lingkungan dan Kebijaksanaan Lingkungan Nasional, Penerbit Airlangga University Press, Surabaya.

Salim H.S.,S.H.,M.S., 2003, Hukum Kontrak, Penerbit Sinar Grafika, Jakarta

\section{Peraturan Perundang-undangan :}

Kitab Undang-Undang Hukum Perdata.

Undang-Undang Republik Indonesia Nomor 23 Tahun 1997 Tentang 
PERSPEKTIF Volume X No.3 Tahun 2005 Edisi Juli

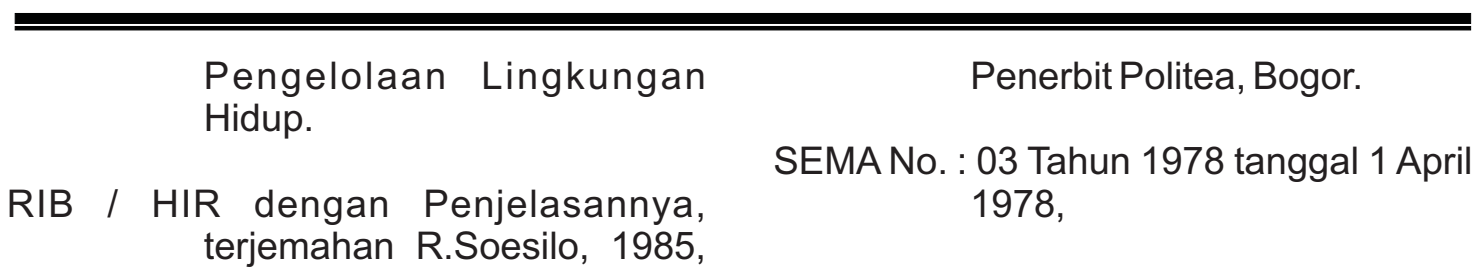

